\title{
Effect of Dietary Fiber, Genetic Strain and Age on the Digestive Metabolism of Broiler Chickens
}

\section{-Author(s)}

Krás RV 1

Kessler A de $\mathrm{M}^{1}$

Ribeiro $\mathrm{AML}^{1}$

Henn JD ${ }^{1}$

Bockor $\mathrm{L}^{1}$

Sbrissia $\mathrm{AF}^{2}$

Departamento de Zootecnia, Universidade Federal do Rio Grande do Sul - UFRGS. Porto Alegre, RS.

2 Departamento de Produção Animal e Alimentos, Universidade do Estado de Santa Catarina - UDESC. Lages, SC.

\section{Mail Adress}

${ }^{*}$ Corresponding author e-mail address Rodrigo Vieira Krás

Av. Bento Gonçalves, 7712

91.540-000 Porto Alegre, RS, Brasil

E-mail: rodrigokras@yahoo.com.br

\section{nKeywords}

Age, fiber, metabolism, pair-fed, strain

*Part of this article was published in the proceedings of Reunião Anual da Sociedade Brasileira de Zootecnia, 2010 and 2011.

\section{ABSTRACT}

In this study, 360 male broilers, out of which 240 of a fast-growing strain (Cobb500), and 120 of a slow-growing strain (Label Rouge), were used to evaluate the effect of dietary fiber on digesta transit time and digestive metabolism during the period of 1 to 42 days of age. A completely randomized experimental design with a $3 \times 2$ factorial arrangement was applied, consisting of three groups of birds (slow-growing - SG; fast-growing fed ad libitum - FGAL; and fast-growing pair-fed with SG broilers - FGPF) and two iso-protein diets (a $3100 \mathrm{kcal}$ ME/kg low-fiber diet -LFD- and a $2800 \mathrm{kcal} \mathrm{ME} /$ $\mathrm{kg}$ high-fiber diet -HFD- with 14\% wheat bran and 4\% oat hulls). HFD-fed birds presented lower ME retention $(p<0.001)$ and lower dry matter metabolizability (DMM) $(p<0.001)$, which is possibly related to the shorter digesta transit time observed in these birds $(p<$ 0.001). DMM was reduced with age, whereas metabolizable energy remained almost constant $(p<0.001)$ independently of strain. This may be related to the increase in feed intake as birds age. The slowgrowing strain did not present better utilization of the high-fiber diet as compared to the fast-growing strain in none of the analyzed ages, even though showing a significant better use of fiber and dietary energy from 31 days of age.

\section{INTRODUCTION}

Dietary fiber (DF) is poorly digested by poultry, and consequently contribution to the nutritional value of feeds is uncertain (Ferreira, 994). Otherwise, the use of alternative ingredients derived from biofuel production and that have with higher fiber content than corn and soybean meal would be more common in poultryuct fiber. Dietary fiber chemically includes non-starch polysaccharides such as cellulose, arabinoxylans, inulin, chitins, pectins, beta-glucans and phenolic polymer lignin that are present in the cell wall of plants (Bach Knudsen, 2001). Analytically, DF is usually considered as part of the dietary components that remain after the extraction with a neutral detergent solution, according to the method described by Van Soest \& Wine (1967) it is known as neutral detergent fiber (NDF).

Several studies have shown that dietary metabolizable energy (ME) increases as birds age (Sell, 1996; Zelenka, 1968; Batal \& Parsons, 2002). Shires et al. (1987) found lower feed passage rates in older birds, and suggested that the exposure of the diet for a longer period to microbial fermentation in the caeca may increase DF digestibility. On the other hand, Siregar \& Farrel (1980) observed that ME values were not influenced by broiler age, whereas Bartov (1988) reported 
ME decrease with age. It must be noted that the feed composition table of the NRC (1994) presents a single ME value for each feedstuff, and does not take into consideration digestibility changes in broilers of different ages.

Commercial broiler strains have been selected for high growth rate and high feed efficiency based on the use of high digestibility diets with no ME limitations. This selection promoted changes in digestive form shape and functions that may have reduced the utilization of low-digestibility diets (Shires et al., 1987). On the other hand, low-performance genetic strains were not submitted to the same selection pressure; these birds are usually reared under alternative poultry production systems, and may be better adapted to lower quality diets.

This study aimed at comparing digesta transit time and diet metabolizability responses of a commercial fast-growing broiler strain to a slow-growing strain fed diets with increasing fiber levels, and determine the age or development phase when the utilization of dietary components is optimal, relating digestive transit time to nutrient metabolizability as influenced by dietary fiber.

\section{MATERIAL AND METHODS}

In this study, 360 male broilers were used, out of which 240 were of a fast-growing commercial strain (Cobb), and 120 of a slow-growing strain (Label Rouge). Birds were housed in 36 battery cages with 10 birds each, in a environmentally-controlled room with $24 \mathrm{~h}$ of light per day, from 1 to 42 days of age.

During the first four experimental days, all birds were fed a single pre-starter feed ad libitum. From day five, two iso-protein diets were fed: a low-fiber diet (LFD), based on corn and soybean meal, with $3100 \mathrm{kcal}$ $\mathrm{ME} / \mathrm{kg}$; or a high-fiber diet (HFD), based on the LFD, to which $14 \%$ wheat bran and $4 \%$ oat hulls were added, containin $2800 \mathrm{kcal} \mathrm{ME} / \mathrm{kg}$, which corresponded to an increase of $7.7 \%$ in neutral detergent fiber. The LFD and the pre-starter diet were formulated with nutritional levels similar to those recommended by Rostagno et al. (2005). A single experimental diet was fed during the entire period to each treatment group to allow comparing diet digestibility among different bird ages (Table 1).

Diets were fed to three different groups of 120 each: slow-growing Label Rouge birds fed ad libitum (SG), Cobb500 birds fed ad libitum (FGAL), and Cobb500 birds pair-fed with Label Rouge birds (FGPF).
This last group was housed one day after the Label Rouge birds in order to receive the same amount of feed consumed by the Label group in the previous day to evaluate digestibility at the same feed intake. Pairfeeding was performed according to diet type, i.e., FGPF birds were fed once a day with the same amount of feed consumed by Label fed LFD or Label fed HFD during the previous day.

Table 1 - Nutritional composition of the experimental diets on fresh matter basis (FM).

\begin{tabular}{lccc}
\hline Diets & Pre-starter & Low fiber & High fiber \\
\hline Analyzed composition (\% FM) & & & \\
\hline Dry matter (\%) & 88.71 & 88.38 & 88.56 \\
Neutral detergent fiber (\%) & 11.05 & 11.81 & 19.51 \\
Acid detergent fiber (\%) & 2.55 & 3.63 & 7.37 \\
Crude protein (\%) & 22.83 & 19.72 & 19.95 \\
Ashes (\%) & 5.21 & 5.01 & 5.3 \\
\hline Calculated composition 1 & & & \\
\hline Metabolizable energy (kcal/kg) & 3050 & 3100 & 2800 \\
\hline Crude fiber (\%) & - & 3.12 & 5.19 \\
Calcium (\%) & 1 & 0.93 & 0.93 \\
Available phosphorus (\%) & 0.46 & 0.44 & 0.44 \\
Sodium (\%) & 0.23 & 0.2 & 0.2 \\
\hline Digestible arginine (\%) & 1.19 & 1.14 & 1.15 \\
Digestible lysine (\%) & 1.3 & 1.14 & 1.14 \\
\hline Digestible methionine (\%) & 0.62 & 0.54 & 0.54 \\
Digestible Met + Cys (\%) & 0.94 & 0.83 & 0.83 \\
\hline Digestible tryptophan (\%) & 0.21 & 0.21 & 0.21 \\
Digestible threonine (\%) & 0.86 & 0.74 & 0.74 \\
Choline (mg/kg) & 1500 & 1450 & 1450 \\
\hline
\end{tabular}

${ }^{1}$ Levels calculated according to Rostagno et al. (2005).

A completely randomized experimental design in a $3 \times 2$ factorial arrangement, with 6 treatments and 6 replicates each, was applied. Treatments consisted of three groups of birds and two dietary fiber levels.

Digestive tract (DT) relative weight was evaluated 21 e and 42 days of age representative bird per replicate. The DT was removed, rinsed of digesta residues, and divided into two sections: the anterior section included the segment from the esophagus to the gizzard, whereas the posterior section included the segment from the duodenum to the vent. The relative weights of the total digestive tract (DTW), anterior section (DTWas), and posterior (DTWps) sections were calculated as a percentage of live weight.

Digesta transit time (DTT) was evaluated at 19 and 38 days of age, using $0.5 \%$ ferric oxide $\left(\mathrm{Fe}_{2} \mathrm{O}_{3}\right)$ in the experimental diets (no fasting time was used), and the time in minutes elapsed between marker supply and its appearance in $60 \%$ of the excreta in the tray was recorded. 
The following metabolizability and digestibility responses were evaluated: dry matter metabolizability (DMM), organic matter metabolizability (OMM), crude protein metabolizability (CPM), gross energy metabolizability (GEM); neutral detergent fiber digestibility (NDFD), acid detergent fiber digestibility (ADFD), and dietary metabolizable energy corrected for null nitrogen balance (AMEn). These responses were obtained by total excreta collection during four periods of digestibility assessment of three days each: 9-11, 19-21, 30-32, and 40-42 days of age, corresponding to intermediate days of $10,20,31$, and 41 , respectively.

Dry matter, ashes, organic matter, and crude protein of feeds and excreta were determined according to the methods of the AOAC (1995). NDF and ADF contents in feeds and excreta were determined according to Goering and Van Soest (1970). For the determination of NDF in the diets, $0.5 \mathrm{~mL} \alpha$-amylase per $\mathrm{L}$ of neutral detergent solution was used (Van Soest et al. 1991). Gross energy of feeds and excreta were determined using an isoperibolic calorimeter (IKA WERKE, model C2000).

Responses were submitted to analysis of variance using the statistical software package Statgraphics Plus 4.1 (Manugistics, 1997). Means were compared using the test of Student-Newman-Keuls (SNK) at 5\% significance level. The effect of age on metabolizability and digestibility indexes was evaluated using the procedure of repeated measures between periods using the model Proc Mixed of SAS, and means were compared using the Least-Square-Difference test (LSD).

\section{RESULTS AND DISCUSSION}

\section{Digestive tract weight and digesta transit time}

There was no effect of interaction between the studied factors on the weight of the digestive tract and its segments, or on digesta transit time (Table 2). Dietary fiber content did not influence digestive tract weights, except for DTWas at 21 days of age, which was higher in birds fed the HFD $(p<0.001)$. This response is related to the higher activity of the gizzard, which resulted in its higher relative weight. According to Jorgensen et al. (1996), DTW, and particularly caeca weight, increases only when dietary fiber level was higher than that used in the present experiment. SG birds presented, in general, higher digestive tract weight as compared to the other groups. This response is partially explained by the lower final live weight of SG birds, which resulted in a higher DT weight relative to body weight. However, the higher DTWas at 21 days and DTWps at 38 days relative to FGPF birds indicates development differences, as their live weights were not considerably different.

Digesta transit time (DTT) at 19 days of age was not significantly influenced by dietary fiber level. However, at 38 days, DTT was lower in birds fed the HFD ( $p<0.001)$, which is consistent with the findings of Shires et al. (1987). Warpechowski (1996) observed a significantly lower DTT when feeding adult cockerels with a diet containing $8.3 \%$ higher NDF levels as

Table 2 - Relative digestive tract weight (DTW) of 21- and 42-d-old and digesta transit time (DTT) of 19- and 38-old slowgrowing and fast-growing broilers divided into three groups (SG, FGAL, FGPF) and fed diets with two fiber levels.

\begin{tabular}{|c|c|c|c|c|c|c|c|c|}
\hline \multirow[t]{2}{*}{ Age } & \multicolumn{3}{|c|}{--------------- 21 d ---------------- } & \multirow{2}{*}{$\begin{array}{l}19 \mathrm{~d} \\
\text { DTT }\end{array}$} & \multicolumn{3}{|c|}{--------------- 42 d --------------- } & \multirow{2}{*}{$\begin{array}{l}38 d \\
\text { DTT }\end{array}$} \\
\hline & DTW & DTWas & DTWps & & DTW & DTWas & DTWps & \\
\hline Diet & \multicolumn{3}{|c|}{----------------- \% LW ---------------- } & Minutes & \multicolumn{3}{|c|}{ 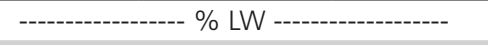 } & Minutes \\
\hline LFD & 8.32 & 3.74 & 4.59 & 276 & 5.39 & 2.76 & 2.63 & 296 \\
\hline HFD & 8.96 & 4.38 & 4.58 & 265 & 5.73 & 3.00 & 2.73 & 262 \\
\hline \multicolumn{9}{|l|}{ Group } \\
\hline SG & $9.34^{\mathrm{a}}$ & $4.65^{\mathrm{a}}$ & 4.69 & $341^{\text {a }}$ & $6.65^{\mathrm{a}}$ & $3.21^{\mathrm{a}}$ & $3.44^{\mathrm{a}}$ & $322^{\mathrm{a}}$ \\
\hline FGAL & $8.20^{b}$ & $3.60^{b}$ & 4.60 & $282^{b}$ & $4.46^{c}$ & $2.29^{b}$ & $2.17^{c}$ & $319^{a}$ \\
\hline FGPF & $8.38^{b}$ & $3.93^{b}$ & 4.45 & $189^{c}$ & $5.57^{b}$ & $3.14^{\mathrm{a}}$ & $2.43^{b}$ & $195^{b}$ \\
\hline \multirow[t]{2}{*}{ SEM } & 0.60 & 0.27 & 0.44 & 16.5 & 0.36 & 0.27 & 0.20 & 18.1 \\
\hline & & 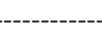 & - & ------- Pr & ---- & ------ & -1---- & \\
\hline Diet & NS & *** & NS & NS & NS & NS & NS & $* * *$ \\
\hline Bird group & * & $\star * *$ & NS & $* * *$ & $* * *$ & $\star * *$ & $\star * *$ & $\star * *$ \\
\hline Interaction & NS & NS & NS & NS & NS & NS & NS & NS \\
\hline
\end{tabular}

a-c Means followed by different letters in the same column are significantly different by the SNK test ( $p<0.05)$. DTWas=relative weight of the anterior section of the digestive tract - from the esophagus to the gizzard; DTWps=relative weight of the posterior section of the digestive tract - from the duodenum to the vent; LFD=low-fiber diet; HFD=high-fiber diet; SG=slow growing strain fed ad libitum; FGAL=fast growing strain fed ad libitum; FGPF=fast growing strain pair-fed with $S G$; $S E M=s t a n d a r d$ error of the mean; * $=$ < < 0.05; ${ }^{* *}=p<0.01 ;{ }^{* * *}=p<0.001 ; N S=$ not significant. 
compared to a basal diet. The transit time obtained in the present study was higher than that found by Cortés et al. (2009), d, using the same methodoogy and, found an average transit time of 228 minutes in 21-d-old broilers.

SG birds presented higher DTT as compared to FGAL at 19 days of age $(p<0.001)$. At 38 days, there were no significant differences between these groups. DTT was considerably lower in the FGPF group, both at 19 and 38 days $(p<0.001)$ relative to the other groups. Larbier \& Leclerq (1992) found that transit time is lower in bird submit a long fasting times before feeding, which was the case of the FGPF birds. However, the observed DTT was not only due to fasting, but also to the fact that the virtually empty digestive tract allowed the rapid dilution of the marker in the liquid phase of the digesta. Perhaps a different methodology should be more appropriate in this case.

\section{Digestibility}

Digestibility responses, corresponding to the ages of 10, 20,31, and 41 days, are presented in Tables 3 e 4. The significant interactions between the studied factors observed at 10 and 20 days of age did not contribute much to the discussion, as they were not consistent and did not present biological coherence. In all evaluated ages, birds fed the HFD presented lower DMM, OMM, GEM and NDFD and AMEn $(p<0.001)$. Crude protein metabolizability was not influenced by fiber level because the diets contained equal protein levels. HFD-fed birds also presented, in general, higher ADF digestibility $(p<0.001)$, which may be related to the low amount of ADF in the low-fiber diet.

The effect of fiber in the present experiment is consistent with the findings of Jorgensen et al. (1996) and Pinheiro et al. (2008), who showed a significant reduction in nutrient digestibility as fiber level increased in broiler diets.

As to bird group, at 10 days of age, the metabolizability of the diet and its fractions was higher in FGPF birds $(p<0.001)$. Several authors found better nutrient digestibility when there was moderate feed intake restriction (Teeter et al., 1985; Yalda et al., 1996; Bonnet et al., 1997). At 20 days of age, SG and FGPF birds were similar to each other and significantly superior to FGAL birds as to DMM, OMM, GEM, and AMEn $(p<0.001)$. At 31 days of age, birds presented similar metabolism values, except for fiber digestibility, which was higher in SG birds as compared to FGPF $(p<0.01)$. At 41 days of age, DMM, OMM, and NDFD were not influenced by bird group, while SG birds presented significantly higher GEM $(p<0.01)$, AMEn $(p<0.001)$ and ADFD $(p<0.001)$ values.

The SG group presented higher ADFD and similar NDFD as compared to the other groups only during the last two periods, possibly indicating the higher development of the digestive tract of this strain, which allowed better fiber utilization.

Table 3 - Metabolizability and digestibility coefficients of 10- and 20-d-old slow-growing and fast-growing broilers divided into three groups (SG, FGAL, FGPF) and fed diets with two fiber levels.

\begin{tabular}{|c|c|c|c|c|c|c|c|c|c|c|c|c|c|c|}
\hline \multirow[t]{2}{*}{ Age } & \multicolumn{7}{|c|}{------------------------------- 10 d ----------------------------- } & \multicolumn{7}{|c|}{------------------------------ 20 d ------------------------------- } \\
\hline & DMM & OMM & CPM & GEM & NDFD & ADFD & AMEn & DMM & OMM & CPM & GEM & NDFD & ADFD & AMEn \\
\hline & \multicolumn{6}{|c|}{------------------------------ \% -------------------------- } & $\mathrm{kcal} /$ & \multicolumn{6}{|c|}{------------------------------- \% --------------------------- } & $\mathrm{kcal} /$ \\
\hline Diets & & & & & & & kgDM & & & & & & & kgDM \\
\hline LFD & 76.46 & 78.54 & 61.66 & 79.23 & 43.40 & 23.82 & 3498 & 74.59 & 76.88 & 62.78 & 77.99 & 31.55 & 12.71 & 3442 \\
\hline HFD & 69.01 & 71.34 & 62.65 & 71.93 & 35.30 & 27.02 & 3110 & 67.09 & 69.36 & 61.08 & 70.36 & 26.40 & 19.17 & 3037 \\
\hline \multicolumn{15}{|l|}{ Bird group } \\
\hline SG & $71.25^{b}$ & $73.43^{b}$ & $57.14^{c}$ & $74.58^{b}$ & $34.77^{b}$ & 24.97 & $3272^{b}$ & $71.52^{\mathrm{a}}$ & $73.64^{a}$ & $61.63^{b}$ & $75.13^{\mathrm{a}}$ & $27.91^{b}$ & 16.50 & $3284^{a}$ \\
\hline FGAL & $72.37^{b}$ & $74.56^{b}$ & $61.37^{b}$ & $74.96^{b}$ & $41.66^{a}$ & 25.10 & $3277^{b}$ & $68.90^{b}$ & $71.18^{b}$ & $59.52^{c}$ & $72.26^{b}$ & $26.75^{b}$ & 14.53 & $3158^{b}$ \\
\hline FGPF & $74.57^{\mathrm{a}}$ & $76.83^{a}$ & $67.96^{a}$ & $77.21^{\mathrm{a}}$ & $41.63^{a}$ & 26.20 & $3362^{a}$ & $72.09^{a}$ & $74.53^{\mathrm{a}}$ & $64.63^{a}$ & $75.14^{\mathrm{a}}$ & $32.27^{a}$ & 16.79 & $3276^{a}$ \\
\hline SEM & 1.17 & 1.13 & 2.21 & 1.05 & 2.67 & 3.04 & 44.1 & 1.02 & 0.95 & 1.81 & 0.96 & 2.66 & 2.66 & 39.8 \\
\hline Diet & $\star * *$ & $* * *$ & NS & $* * *$ & $* * *$ & * & $\star * *$ & $\star * *$ & $* * *$ & * & $\star \star \star$ & $* * *$ & $\star * *$ & $\star * *$ \\
\hline Group & $\star * *$ & $\star * \star$ & $\star \star *$ & $\star \star *$ & $\star * *$ & NS & $\star \star \star *$ & $\star * *$ & $\star * *$ & $\star * *$ & $\star \star *$ & ** & NS & $\star * \star$ \\
\hline Interaction & NS & NS & NS & NS & NS & * & NS & NS & NS & * & NS & * & * & NS \\
\hline
\end{tabular}

a-c Means followed by different letters in the same column are significantly different by the SNK test $(p<0.05)$. DMM=dry matter metabolizability; OMM=0rganic matter metabolizability; CPM=crude protein metabolizability; GEM=gross energy metabolizability; NDFD=neutral detergent fiber digestibility; $A D F D=a c i d$ detergent fiber digestibility; $A M E n=$ dietary apparent metabolizable energy level corrected for nitrogen; LFD=low-fiber diet; HFD: high-fiber diet; SG=slow growing strain fed ad libitum; FGAL=fast growing strain fed ad libitum; FGPF=fast growing strain pair-fed with SG; SEM: standard error of the mean; ${ }^{*}=p<0.05 ;{ }^{* *}=p<0.01 ;{ }^{* *}=p<0.001$; NS=not significant. 
Table 4 - Metabolizability and digestibility coefficients of 31- and 41-d-old slow-growing and fast-growing broilers divided into three groups (SG, FGAL, FGPF) and fed diets with two fiber levels.

\begin{tabular}{|c|c|c|c|c|c|c|c|c|c|c|c|c|c|c|}
\hline \multirow[t]{2}{*}{ Age } & \multicolumn{7}{|c|}{ 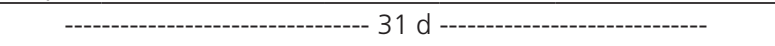 } & \multicolumn{7}{|c|}{ 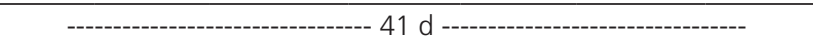 } \\
\hline & DMM & OMM & CPM & GEM & NDFD & ADFD & AMEn & DMM & OMM & CPM & GEM & NDFD & ADFD & AMEn \\
\hline & \multicolumn{6}{|c|}{ 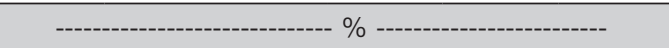 } & $\mathrm{kcal} /$ & \multicolumn{6}{|c|}{-------------------------------- \% ----------------------------- } & $\mathrm{kcal} /$ \\
\hline Diets & & & & & & & kgDM & & & & & & & kgDM \\
\hline LFD & 73.98 & 76.88 & 59.58 & 77.88 & 28.30 & 7.43 & 3432 & 74.73 & 77.70 & 56.28 & 78.06 & 29.18 & 10.02 & 3450 \\
\hline HFD & 66.64 & 69.53 & 59.28 & 70.84 & 21.96 & 13.71 & 3122 & 66.16 & 69.07 & 54.88 & 70.39 & 23.74 & 15.08 & 3114 \\
\hline \multicolumn{15}{|l|}{ Bird group } \\
\hline SG & 70.64 & 73.20 & 57.22 & 75.10 & $28.01^{a}$ & $15.09^{a}$ & $3318^{a}$ & 70.65 & 73.53 & $50.30^{b}$ & $75.65^{a}$ & 28.90 & $18.84^{\mathrm{a}}$ & $3365^{a}$ \\
\hline FGAL & 70.22 & 73.00 & 58.41 & 74.43 & $25.62^{\mathrm{ab}}$ & $9.63^{b}$ & $3283^{a b}$ & 69.35 & 72.42 & $51.50^{b}$ & $73.20^{b}$ & 26.55 & $11.98^{b}$ & $3247^{b}$ \\
\hline FGPF & 70.08 & 73.40 & 62.67 & 73.54 & $21.75^{b}$ & $6.99^{b}$ & $3230^{b}$ & 71.33 & 74.20 & $64.94^{a}$ & $73.82^{b}$ & 23.94 & $6.82^{\mathrm{b}}$ & $3236^{b}$ \\
\hline SEM & 1.41 & 1.29 & 3.55 & 1.20 & 3.65 & 3.91 & 50.2 & 1.47 & 1.37 & 2.97 & 1.42 & 4.10 & 5.03 & 60.7 \\
\hline Diet & $* * *$ & $* * *$ & NS & $\star * *$ & ** & ** & $\star \star \star *$ & $\star * *$ & $* * *$ & NS & $\star * \star$ & ** & * & $* * *$ \\
\hline Group & NS & NS & NS & NS & * & ** & * & NS & NS & $\star * \star$ & ** & NS & $* * *$ & $\star * *$ \\
\hline Interaction & NS & NS & NS & NS & NS & NS & NS & NS & NS & NS & NS & NS & NS & NS \\
\hline
\end{tabular}

a-c Means followed by different letters in the same column are significantly different by the LSD test $(p<0.05)$. DMM=dry matter metabolizability; OMM=0rganic matter metabolizability; CPM=crude protein metabolizability; GEM=gross energy metabolizability; NDFD=neutral detergent fiber digestibility; $A D F D=a c i d$ detergent fiber digestibility; AMEn=dietary apparent metabolizable energy level corrected for nitrogen; LFD=low-fiber diet; HFD=high-fiber diet; SG=slow growing strain fed ad libitum; FGAL=fast growing strain fed ; FGPF=fast growing strain pair-fed with SG; $S E M=$ standard error of the mean; ${ }^{*}=p<0.05 ;{ }^{* *}=p<0.01 ;{ }^{* *}=p<0.001$; NS=not significant.

The FGPF group showed higher DM, OM and GE metabolizability at $10 \mathrm{~d}$, bendency trend was not followed at 20, 31 and $41 \mathrm{~d}$ of age. This may be related with the increase in feed restriction severity as a function of their genetic potential for growth. During the subsequent phases, these restricted-voracity were highly when at the time feed supplied, leading to lower transit time, and consequently, lower nutrient digestibility. It must be noted that these responses are not directly related to $F C R$, which was better in the final period in this group as compared to the others. However, the higher GEM and AMEn values of the SG groups at 41 days of age are consistent with their higher DTW at 42 days of age.

\section{Comparison among periods}

Using the analysis of repeated measures in time (Table 5), it was possible to conclude that all evaluated parameters presented significantly lower values during the periods after 10 days of age $(p<0.001)$, except for AMEn, which was lower only at 20 days as compared to the other periods $(p<0.01)$. The reduction in nutrient digestibility and AMEn stability as birds aged disagree with the findings of Zelenka (1968) and Batal \& Parsons (2002), who showed that diet utilization improved with age. Carré et al. (1995) also observed higher carbohydrate digestibility in mature birds, which was attributed to their higher intestinal fermentation capacity and their higher efficiency of absorption of fermentation products.

The better digestibility on day 10 observed in the present study may be related to higher digesta retention in the digestive tract during the first weeks of life, and later with the increase in feed intake with age. According to Sell (1996), the gastrointestinal tract reaches higher proportion relative to body mass between 6 to 8 days after hatching. Therefore, during this period there is a higher fill effect in the gut, because the digestive tract grows faster than the rest of the body mass, promoting higher nutrient retention in the lumen of the digestive tract and consequent reduction in fecal excretion, thereby increasing digestibility. In the present study, relative DT weight at 21 days (8.6\%) was higher as compared to 42 days (5.6\%).

The interactions observed when the factor age was included in the analysis of repeated measures reflect the effects shown in Tables 3 and 4 by age, and therefore, do not add much to the previous discussion. Rather, they indicate the amplification of the significant effects when the number of observations is increased in the joint analysis of the four ages studied.

\section{CONCLUSIONS}

Digestive tract weight and digesta transit time were not influenced by broiler strain (slow-growing or fast- 
growing). The high-fiber diet increased the weight of the anterior section of the digestive tract and decreased digesta transit time. Independent of the genetic strain, dietary fiber reduced nutrient digestibility. The slowgrowing Label Rouge broilers presented better fiber-diet digestibility than the fast-growing strain broilers after 31 days of age, possibly due to the higher development of the digestive tract in this phase, however, the utilization of high-fiber diet was similar along the experimental period, independently of genetic.

Table 5 - Effect of diet, bird group, and age, obtained by analysis of repeated measures of the evaluated periods, on metabolizability and digestibility coefficients of slowgrowing and fast-growing broilers divided into three groups (SG, FGAL and FGPF) fed diets with two fiber levels.

\begin{tabular}{|c|c|c|c|c|c|c|c|}
\hline & DMM & OMM & CPM & GEM & NDFD & ADFD & AMEn \\
\hline Diets & & & & $\%-$ & & & $\begin{array}{l}\mathrm{kcal} / \\
\mathrm{kgDM}\end{array}$ \\
\hline LFD & 74.94 & 77.50 & 59.65 & 78.29 & 32.89 & 12.64 & 3455.39 \\
\hline HFD & 67.23 & 69.82 & 59.90 & 70.88 & 26.85 & 18.75 & 3096.07 \\
\hline SEM & 0.21 & 0.20 & 0.46 & 0.19 & 0.55 & 0.71 & 8.04 \\
\hline \multicolumn{8}{|l|}{ Group } \\
\hline SG & $71.02^{b}$ & $73.50^{b}$ & $56.57^{b}$ & $75.12^{\mathrm{a}}$ & 29.90 & $19.14^{a}$ & $3309.91^{a}$ \\
\hline FGAL & $70.21^{c}$ & $72.84^{b}$ & $57.70^{b}$ & $73.71^{b}$ & 30.15 & $15.31^{b}$ & $3241.51^{c}$ \\
\hline FGPF & $72.02^{\mathrm{a}}$ & $74.64^{a}$ & $65.05^{a}$ & $74.93^{a}$ & 29.56 & $12.63^{c}$ & $3275.76^{b}$ \\
\hline SEM & 0.26 & 0.24 & 0.57 & 0.23 & 0.68 & 0.87 & 9.84 \\
\hline \multicolumn{8}{|l|}{ Age (d) } \\
\hline 10 & $72.73^{a}$ & $74.94^{\mathrm{a}}$ & $62.16^{a}$ & $75.58^{a}$ & $39.35^{a}$ & $25.42^{\mathrm{a}}$ & $3303.82^{\mathrm{a}}$ \\
\hline 20 & $70.84^{b}$ & $73.12^{b}$ & $61.93^{\mathrm{a}}$ & $74.17^{b}$ & $28.98^{b}$ & $16.33^{b}$ & $3239.59^{b}$ \\
\hline 31 & $70.31^{b}$ & $73.20^{\mathrm{b}}$ & $59.43^{b}$ & $74.36^{b}$ & $24.68^{c}$ & $8.48^{d}$ & $3277.17^{a}$ \\
\hline 41 & $70.45^{b}$ & $73.38^{b}$ & $55.58^{c}$ & $74.22^{b}$ & $26.46^{c}$ & $12.55^{c}$ & $3282.33^{a}$ \\
\hline \multirow[t]{2}{*}{ SEM } & 0.30 & 0.28 & 0.65 & 0.27 & 0.78 & 1.01 & 11.4 \\
\hline & & - & ------- & Probabil & lity ----- & - & ------- \\
\hline Diet (D) & $* * *$ & $* * *$ & NS & $* * *$ & $* * *$ & $* * *$ & $* * *$ \\
\hline $\begin{array}{l}\text { Group } \\
\text { (G) }\end{array}$ & $* * *$ & $* * *$ & $* * *$ & $* * *$ & NS & $* * *$ & $* * *$ \\
\hline Age (A) & $* * *$ & $* * *$ & $* * *$ & $* * *$ & $* * *$ & $* * *$ & $* *$ \\
\hline$D \times G$ & NS & NS & NS & NS & NS & NS & NS \\
\hline$D \times A$ & NS & NS & NS & NS & NS & NS & * \\
\hline$G \times A$ & $* * *$ & $* * *$ & $* * *$ & $* * *$ & $* * *$ & $* * *$ & $* * *$ \\
\hline $\begin{array}{l}D \times G \\
\times A\end{array}$ & NS & * & NS & NS & $* *$ & ** & NS \\
\hline
\end{tabular}

${ }^{a-d}$ Means followed by different letters in the same column are significantly different by the $L S D$ test $(P<0.05)$. DMM=dry matter metabolizability; OMM=organic matter metabolizability; $\mathrm{CPM}=$ crude protein metabolizability; $\mathrm{GEM=gross} \mathrm{energy} \mathrm{metaboliz-}$ ability; NDFD=neutral detergent fiber digestibility; $A D F D=$ acid detergent fiber digestibility; AMEn=dietary apparent metabolizable energy level corrected for nitrogen; LFD=low-fiber diet; HFD=high-fiber diet; SG=slow growing strain fed FGAL=fast growing strain fed; FGPF=fast growing strain pair-fed with $S G$; $S E M=$ standard error of the mean; ${ }^{*}=p<0.05 ;{ }^{* *}=p<0.01 ;{ }^{* *}=p<0.001 ; N S=$ not significant.

\section{ACKNOWLEDGEMENTS}

The authors thank Coordenação de Aperfeiçoamento de Pessoal de nível Superior (CAPES), Ministério da Educação, Brazil, and Conselho Nacional de Desenvolvimento Científico e Tecnológico (CNPq), Ministério da Ciência e Tecnologia, Brazil for funding this study.

\section{REFERENCES}

Association of Official Analytical Chemists. Official methods of Analysis. $16^{\text {th }}$ ed. Arlington: AOAC International; 1995.

Bach Knudsen KE. The nutritional significance of "dietary fibre" analysis. Animal Feed Science and Technoloy 2001; 90:3-20.

Batov I. Effect of age of broiler chicks and method of determination on the metabolizable energy of corn. Proceedings of the $18^{\text {th }}$ World Poultry Congress; 1988;Nagoya., Japan. p. 787-789.

Batal $A B$, Parsons CM. Effects of age on nutrient digestibility in chicks fed different diets. Poultry Science 2002; 81:400-407.

Bonnet S, Geraert PA, Lessire M, Carré B, Guillaumin S. Effect of high ambient temperature on feed digestibility in broilers. Poultry Sciene 197; 76: 857-863

Carré B, Gomez J, Chagneau AM. Contribution of oligosaccharide and polysaccharide digestion, and excreta losses of lactic acid and short chain fatty acids, to dietary metabolisable energy values in broiler chickens and adult cockerels. British Poultry Sciene 1995; 36:611-629.

Cortés MEM, Ribeiro AML, Gianfelice MF, Kessler AM, Moraes ML. Study of methodological variations in apparent nutrient metabolism determination in broiler chickens. Brazilian Journal of Animal Scien 2009;. 38:1921-1927.

Ferreira WM. Os componentes da parede celular vegetal na nutrição de não ruminantes. Simpósio Internacional de Produção de Não-Rumtes. 31thXXXI Reunião Anual da Sociedade Brasileira de Zootecnia; 1994; Maringá, Paraná. Brasil. p.85-113.

Goering HK, Van Soest PJ. Forage fiber analyses (apparatus, reagents, procedures and some applications)[agricultural handboo, 379]. Wash 379, U.S. Departtament of Agriculturon, DC.

Hetland $\mathrm{H}$, Choct M, Svihus B. Role of insoluble non-starch polysaccarides in poultry nutrition. World's Poultry Science Journl 204; 60: 415-422.

Jorgensen $\mathrm{H}$, Zhao X, Bach Knudsen KE, Eggum BO. The influence of dietary fibre source and level on the development of the gastrointestinal tract, digestibility and energy metabolism in broiler chickens. British Journal of Nutrition 1996; 75:379-395.

Larbier M, Leclerq B. Nutrition and feedng of PPoultry. Notingham:, Nottingham University Press2. 305p.

National Research Council. Nutrient Requirements of Poultry. $9^{\text {th }}$ revised edition National Academy Press; 1994; Washington, D.C.

Pinheiro C, Rego JCC, Ramos TA, Silva BKR, Warpechowski MB Digestibilidade dos nutrientes e desempenho de frangos de corte consumindo dietas formuladas com diferentes níveis de fibra e suplementadas com enzimas exógenas. Ciência Animal Brasileia 2008; 9:984-996. 
Rostagno HS. Tabelas brasileiras para aves e suínos: Composição de alimentos e exigências nutricionais. 2 ed. Viçoa: UFV,. Departamento de Zootecnia; 2005.

Sell LJ. Physiological Limitations and potential for improvement in gastrointestinal tract function of poultry. Journal Applied Poultry Researh 1996; 5:96-101

Shires A, Thompson JR, Turner BV, Kennedy PM, Goh YK. Rate of passage of corn-canola meal and corn-soybean meal diets through the gastrointestinal tract of broiler and white leghorn chickens. Poultry Sciene 1987; 66:289-298.

Siregar AP, Farrell DJ. A comparison of the energy and nitrogen metabolism of fed ducklings and chickens. British Poultry Science 1980;21:213227.

Teeter RG, Smith MO. Feed intake effects upon gain, carcass yield, and ration digestibility in broilers force fed five feed intakes. Poultry Science $1985 ; 64: 2155-2160$

Van Soest PJ, Robertson JB, Lewis BA. Methods for dietary fiber, neutral detergent fiber, and non-starch polysaccharides in relation to animal nutrition. Journal Dairy Science 1991;74:3583-3597.

Van Soest PJ, Wine RH. Use of detergents in the analysis of fibrous feeds. Determination of plant cell-wall constituents. Journal of the Association off Official Analytical Chemists 1967;50:50-55.

Warpechowski MB. Efeito da fibra insolúvel da dieta sobre a passagem no trato gastrintestinal de matrizes machos pesados intactos, cecectomizados e fistulados no íleo terminal [dissertação]. Porto Alegre (RS): Universidade Federal do Rio Grande do Sul; 1996.

Yalda AY, Forbes JM. Effects of food intake, soaking time, enzyme and cornflour addition on the digestibility of the diet and performance of broilers given wet food. British Poultry Science 1996;37:797-807.

Zanusso JT, Dionello NJL. Produção avícola alternativa: análise dos fatores qualitativos de frangos de corte tipo caipira. Revista Brasileira de Agrociência 2003;9(3):191-194.

Zelenka J. Influence of the age of chickens on the metabolisable energy values of poultry diets. British Poultry Science 1968;9:135-142. 